\title{
Effect of different modes of pollination on yield parameters of summer squash (Cucurbita pepo L.) in India
}

\section{Devika Rani, Sunita Yadav*, H.D. Kaushik and G. Narendra Kumar}

Department of Entomology, CCS Haryana Agricultural University, Hisar-125004 (Haryana), INDIA

*Corresponding author. E-mail: sunitayadav10@rediffmail.com

Received: July 27, 2015; Revised received: January 1, 2016; Accepted: April 15, 2016

Abstract: Effect of different modes of pollination, viz., without insect pollination, hand-pollination, open-pollination and open-pollination + hand-pollination on yield parameters of 4 summer squash (Cucurbita pepo L.) hybrids viz., Parikrama, Chandra, Chamatkar and Gold Queen was studied at Research Farm of the Department of Entomology, CCS Haryana Agricultural University, Hisar during 2014. Irrespective of different hybrids, the treatment openpollination + hand-pollination and open-pollination produced the maximum number of fruits per plant (73.50 and $71.25 \%$, respectively) followed by hand-pollination $(59.08 \%)$ and no fruits were observed $(0 \%$ fruit set) under without insect pollination treatment. Average fruit weight, fruit polar diameter and equatorial diameter were maximum $(135.30 \mathrm{~g}, 3.74 \mathrm{~cm}$ and $3.47 \mathrm{~cm}$, respectively) under open-pollination + hand-pollination, while these were minimum $(94.81 \mathrm{~cm}, 2.14 \mathrm{~cm}$ and $2.48 \mathrm{~cm}$, respectively) under hand-pollination treatment. These results indicate that honey bees as well as wild pollinators are utmost essential for pollination of summer squash flowers and thus increasing fruit size and yield. Therefore pollinators conservation practices should be followed in summer squash growing areas for getting higher yield and returns.

Keywords: Fruit weight, Hybrids, Pollination, Summer squash, Yield

\section{INTRODUCTION}

Food security and rising food inflation have been the plea of recent times (Tomar, 2013), with the production of food items, especially vegetables gaining utmost concern. Vegetable production not only depends on good agronomic practices but also on the success of pollination. Summer squash, commonly known as vegetable marrow and field pumpkin, is a monoecious plant, grown for both food and medicinal purposes. Both male and female flowers produce nectar but the male flower nectar has a higher sugar concentration. Flowers of both the sexes are typically open only for a single day, after which, the male and insufficiently pollinated female flowers will drop (Free, 1992; Nepi and Pacini, 1993). The pollens of cucurbitaceous crops are sticky, thus, cannot be blown by wind. Therefore, pollinating agents, usually bees, are necessary to transfer pollen from male to female flowers. Large quantity of pollens must be delivered to a female flower if it is to set a marketable fruit. Adequate pollination results into uniform and perfectly formed fruits with even maturity (McGregor, 1976), while incomplete pollination results in to improperly formed, small and misshapen fruits (Hodges and Baxendale, 1991). Kumar (2004) reported that the percent fruit set in cucumber was maximum $(84.29 \%)$ under bee-pollinated + hand-pollinated plots and was minimum (79.99\%) under hand-pollinated plots. Sarwar et al. (2008) observed the highest per cent fruit set in open-pollinated plants with bees $(85.4 \%)$, followed by plants caged with bees $(81.28 \%)$, and noticed the lowest fruit set in plants caged without bees (16.4\%). Thakur and Meena (2008) reported significantly highest percentage of healthy fruits $(92.22 \%)$ in bee pollination as compared to hand $(85.85 \%)$ and open pollination (79.64\%). Similarly weight of fruits (1184.5 $\mathrm{g})$, number of seeds per fruit (472.8), fruit size (28.8 $\mathrm{cm})$ and weight of 1000-seeds (29.14 g) was highest in honey bee pollination as compared to other modes of pollination. Cross-pollination also delivers larger individual fruits. While wild pollinators are typically sufficient for fruit set, addition of honeybees can maximize the number of visits per flower, which results in increasing percent setting and size of the fruit. Hence, it is essential to estimate the contribution of pollinators in pollinating the summer squash flowers. Lot of work had been done in India and abroad on its agronomic practices, medicinal uses, distribution, pollen viability and pistil receptivity (Nepi and Pacini, 1993) but little research has been addressed in India on the role of insect pollinators on fruit production of summer squash. With this aim, the present study was undertaken to study the effect of different methods of pollination on yield parameters in summer squash to ascertain the best mode of pollination to harvest maximum fruits.

\section{MATERIALS AND METHODS}

The experiment comprising four varieties, viz., Parik- 
rama, Chandra, Chamatkar and Gold Queen in combination with four methods of pollination, viz., without insect pollination, hand-pollination, open-pollination and open-pollination + hand-pollination was conducted at Research Farm of the Department of Entomology, CCS Haryana Agricultural University, Hisar during February-March of 2014. The crop was raised under field conditions following the recommended Package of practices.

In hand-pollination, twenty flowers were enclosed with butter paper bags and next day pollinated by hands after taking male flowers from the same plant through touching the anthers by stigma and again covered with butter paper bags. In open-pollination, the twenty female flowers in each variety were exposed to naturally existing native pollinators. In open - pollination + hand - pollination treatment, twenty female flowers were allowed to pollinate by naturally existing native pollinators and were also pollinated by hand. The butters paper bags were used to exclude insect contributing towards pollination.

The rhythmic activity of different insect visitors was recorded at the time of full bloom of summer squash crop. Each fruit picking was done at 15 days interval, and all the fruit parameters were recorded in different treatments. The percent fruit set, fruit weight, fruit length and fruit diameter were recorded at the time of harvest. For each parameter, the mean of 10 observations constituted one replication and there were 4 replications (40 fruits per treatment) under each treatment. Observations on yield parameters for each variety combination were taken 15 days after the flower opening. The mean, range, and standard deviations of the observations were found out. The percent fruit set data underwent angular transformation. No transformations were applied to data on fruit length, fruit diameter and fruit weight. $T$ he data was analyzed by factorial complete randomized design and students t test was used to find out the critical difference value at 5\% level of significance to determine if there were any significant differences on the yield parameters due to various modes of pollination.

\section{RESULTS AND DISCUSSION}

Effect of different modes of pollination on fruit set: The perusal of data presented in table 1 reveals that the mean per cent fruit set in different modes of pollination differed significantly among themselves. Irrespective of different hybrids, the treatment open-pollination + hand-pollination and open-pollination produced the maximum number of fruits per plant (73.50 and $71.25 \%$, respectively) followed by hand-pollination $(59.08 \%)$. The least or zero per cent fruit set was observed in without insect pollination (WIP) treatment, in which, the flowers were excluded from the insect pollination by covering the flower with butter paper bag of size $6 \times 4 \mathrm{~cm}$. Irrespective of different modes of pollination, the mean per cent fruit set in different hybrids of summer squash was 67.43 (Parikrama), 69.17 (Chandra), 66.33 (Chamatkar) and 68.83 (Gold Queen). With respect to different modes of pollination, the per cent fruit set under open-pollination + handpollination for Parikrama, Chandra, Chamatkar and Gold Queen hybrid was 75.50, 73.00, 72.00 and 73.50, respectively, which was again numerically higher than the per cent fruit set under hand-pollination treatment. The interaction between different modes of pollination and different hybrids differed non-significantly.

The data show that the mean per cent fruit set per plant was found to be 54.30 per cent (range 40-60) in Parikrama, 63.00 per cent (range 50-70) in Chandra, 57.00 per cent (range 55-65) in Chamatkar and 62.00 per cent (range 50-75) in Gold Queen in hand-pollinated plants. It was 72.50 per cent (range 60-90) in Parikrama, 71.50 per cent (range 65-80) in Chandra, 70.00 per cent (range 65-85) in Chamatkar and 71.00 per cent (range 60-80) in Gold Queen hybrid in openpollination. The per cent fruit set was recorded zero in all summer squash hybrids under without insect pollination treatment. In open-pollination + handpollination treatment, the per cent fruit set was 75.50 per cent (range 60-85) in Parikrama, 73.00 per cent (range 60-80) in Chandra, 72.00 per cent (range 65-85) in Chamatkar and 73.50 per cent (range65-85) in Gold Queen. Kumar (2004) also reported that the percent fruit set in cucumber, was maximum $(84.29 \%)$ under bee-pollination + hand-pollination, and was minimum (79.99\%) under hand-pollination conditions. In Pakistan, Sarwar et al. (2008) also observed the highest per cent fruit set in cucumber in open pollinated plants with bees $(85.4 \%)$, followed by plants caged with bees $(81.28 \%)$ and the lowest per cent fruit set in plants caged without bees (16.4\%).

Effect of different modes of pollination on fruit equatorial diameter: The data with respect to the effect of modes of pollination on fruit equatorial diameter in different hybrids of summer squash have been given in table 2 . The average fruit equatorial diameter of different hybrids in open-pollination + handpollination $(3.47 \mathrm{~cm})$ was significantly higher than the average fruit diameter in hand-pollination $(2.48 \mathrm{~cm})$ and open-pollination $(2.74 \mathrm{~cm})$ treatments. Irrespective of different modes of pollination, the mean fruit diameter of Gold Queen $(3.03 \mathrm{~cm})$ was recorded maximum and it was par with Chamatkar $(2.91 \mathrm{~cm})$ and Chandra $(2.90 \mathrm{~cm})$ and these three were significantly higher than the mean fruit diameter of Chandra (2.90 $\mathrm{cm})$ and Parikrama $(2.70 \mathrm{~cm})$ hybrid. The interaction between different modes of pollination and different hybrids was non-significant. No fruit formation was observed in treatment without insect pollination.

The perusal of data in table 2 reveals that the mean fruit diameter was recorded $2.47 \mathrm{~cm}$ (range 2.44-3.08 $\mathrm{cm}$ ) in Parikrama, $2.54 \mathrm{~cm}$ (range 2.54-3.86 cm) in Chandra, $2.43 \mathrm{~cm}$ (range 2.10-3.20 cm) in Chamatkar and $2.51 \mathrm{~cm}$ (range 2.50-4.10 cm) in Gold Queen hy- 
Table 1. Effect of different modes of pollination on fruit set in different hybrids of C. pepo.

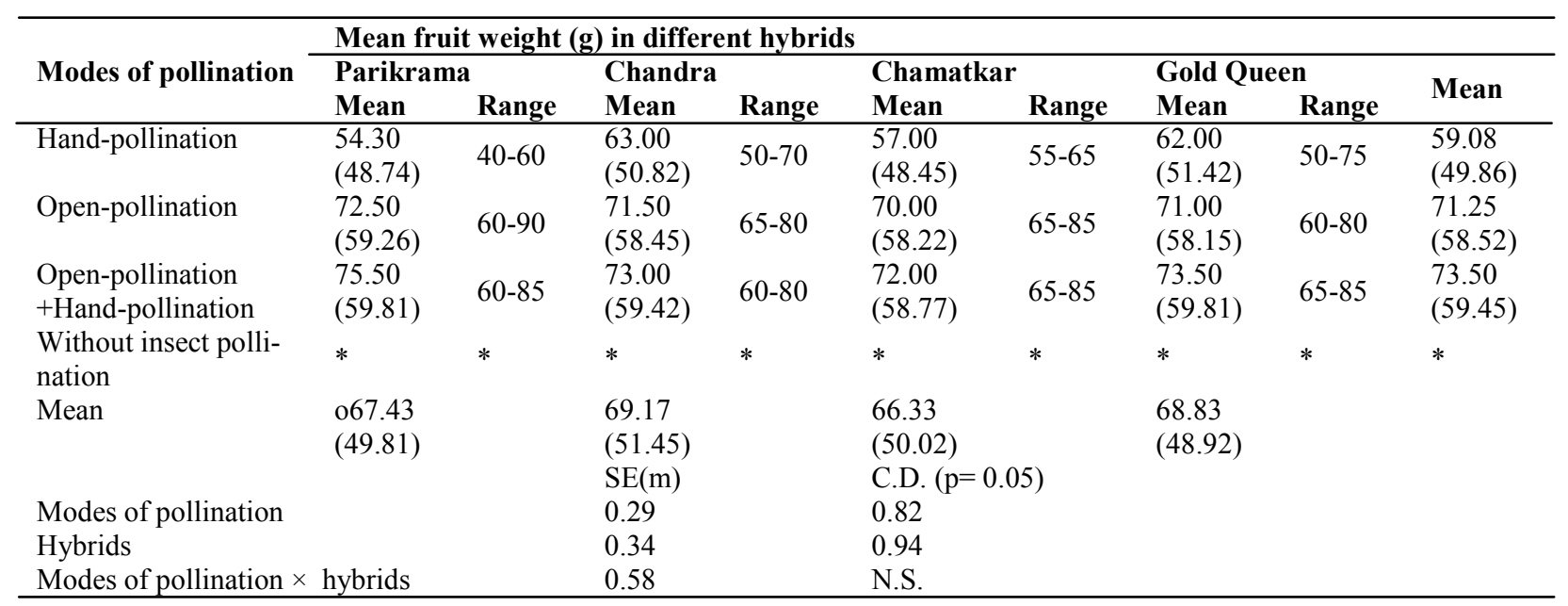

Each value represents mean of 20 observations. * No fruit formation ( $0 \%$ fruit set) was observed under without insect pollination treatment.

Table 2. Effect of different modes of pollination on fruit equatorial diameter in different hybrids of C. pepo.

\begin{tabular}{|c|c|c|c|c|c|c|c|c|c|}
\hline \multirow{3}{*}{ Modes of pollination } & \multicolumn{9}{|c|}{ Mean fruit diameter $(\mathrm{cm})$ in different hybrids } \\
\hline & \multicolumn{2}{|c|}{ Parikrama } & \multicolumn{2}{|c|}{ Chandra } & \multicolumn{2}{|c|}{ Chamatkar } & \multicolumn{2}{|c|}{ Gold Queen } & \multirow{2}{*}{ Mean } \\
\hline & Mean & Range & Mean & Range & Mean & Range & Mean & Range & \\
\hline Hand-pollination & 2.47 & $2.44-3.08$ & 2.54 & $2.54-3.86$ & 2.43 & $2.10-3.20$ & 2.51 & $2.50-3.10$ & 2.48 \\
\hline Open-pollination & 2.73 & $2.40-3.80$ & 2.69 & $2.44-3.21$ & 2.87 & $2.30-3.60$ & 2.69 & $2.65-3.48$ & 2.74 \\
\hline $\begin{array}{l}\text { Open-pollination } \\
+ \text { Hand-pollination }\end{array}$ & 2.90 & $2.10-3.50$ & 3.65 & $3.24-4.23$ & 3.42 & $3.25-4.80$ & 3.90 & $3.98-4.70$ & 3.47 \\
\hline $\begin{array}{l}\text { Without insect polli- } \\
\text { nation }\end{array}$ & $*$ & * & * & * & * & * & * & * & * \\
\hline \multirow[t]{2}{*}{ Mean } & \multirow{2}{*}{\multicolumn{2}{|c|}{2.70}} & \multicolumn{2}{|l|}{2.90} & \multicolumn{2}{|l|}{2.91} & \multicolumn{2}{|l|}{3.03} & \\
\hline & & & & $\mathrm{SE}(\mathrm{m})$ & \multicolumn{2}{|c|}{ C.D. $(p=0.05)$} & & & \\
\hline \multicolumn{3}{|l|}{ Modes of pollination } & & 0.05 & \multicolumn{2}{|c|}{0.21} & & & \\
\hline \multicolumn{3}{|l|}{ Hybrids } & & 0.12 & 0.23 & & & & \\
\hline \multicolumn{3}{|c|}{ Modes of pollination $\times$ hybrids } & & 0.16 & \multicolumn{2}{|l|}{ N.S. } & & & \\
\hline
\end{tabular}

* No fruit formation ( $0 \%$ fruit set) was observed under without insect pollination treatment.

Table 3. Effect of different modes of pollination on fruit polar diameter in different hybrids of C. pepo.

\begin{tabular}{|c|c|c|c|c|c|c|c|c|c|}
\hline \multirow{3}{*}{ Modes of pollination } & \multicolumn{9}{|c|}{ Mean fruit diameter $(\mathrm{cm})$ in different hybrids } \\
\hline & \multicolumn{2}{|c|}{ Parikrama } & \multicolumn{2}{|c|}{ Chandra } & \multicolumn{2}{|c|}{ Chamatkar } & \multicolumn{2}{|c|}{ Gold Queen } & \multirow{2}{*}{ Mean } \\
\hline & Mean & Range & Mean & Range & Mean & Range & Mean & Range & \\
\hline Hand-pollination & 2.14 & $\begin{array}{l}2.12- \\
2.45\end{array}$ & 2.13 & $2.11-2.98$ & 2.17 & $2.11-2.98$ & 2.11 & $2.12-2.64$ & 2.14 \\
\hline Open-pollination & 2.26 & $\begin{array}{l}2.26- \\
2.35\end{array}$ & 2.24 & $2.23-2.69$ & 2.16 & $2.12-2.26$ & 2.95 & $2.92-3.23$ & 2.40 \\
\hline $\begin{array}{l}\text { Open-pollination } \\
\text { +Hand-pollination }\end{array}$ & 3.40 & $\begin{array}{l}2.61- \\
3.92\end{array}$ & 4.12 & $3.62-4.62$ & 3.65 & $3.25-4.20$ & 3.80 & $3.12-4.70$ & 3.74 \\
\hline $\begin{array}{l}\text { Without insect polli- } \\
\text { nation }\end{array}$ & * & $*$ & * & $*$ & * & * & * & * & $*$ \\
\hline \multirow[t]{2}{*}{ Mean } & \multirow{2}{*}{\multicolumn{2}{|c|}{2.60}} & \multirow{2}{*}{\multicolumn{2}{|c|}{$2.83 \quad \mathrm{SE}(\mathrm{m})$}} & \multicolumn{2}{|c|}{$\begin{array}{l}2.66 \\
C(n=005)\end{array}$} & \multirow{2}{*}{\multicolumn{2}{|c|}{2.95}} & \\
\hline & & & & & \multicolumn{2}{|c|}{ C.D. $(p=0.05)$} & & & \\
\hline Modes of pollination & & & \multicolumn{2}{|r|}{0.04} & \multicolumn{2}{|l|}{0.14} & & & \\
\hline \multicolumn{3}{|l|}{ Hybrids } & \multicolumn{2}{|r|}{0.05} & \multicolumn{2}{|l|}{0.83} & & & \\
\hline \multicolumn{3}{|c|}{ Modes of pollination $\times$ hybrids } & \multicolumn{2}{|r|}{0.09} & \multicolumn{2}{|l|}{ N.S. } & & & \\
\hline
\end{tabular}

* No fruit formation ( $0 \%$ fruit set) was observed under without insect pollination treatment.

brid under hand-pollination treatment. It was $2.73 \mathrm{~cm}$ (range 2.40-3.80 cm) in Parikrama, $2.69 \mathrm{~cm}$ (range 2.44-3.21 cm) in Chandra, $2.87 \mathrm{~cm}$ (range 2.30-3.60 $\mathrm{cm}$ ) in Chamatkar and $2.69 \mathrm{~cm}$ (range 2.65-3.48 cm) in Gold Queen hybrid in open-pollinated plants. Similarly, the mean fruit diameter in open-pollination + 
Table 4. Effect of different modes of pollination on fruit weight in different hybrids of C. pepo.

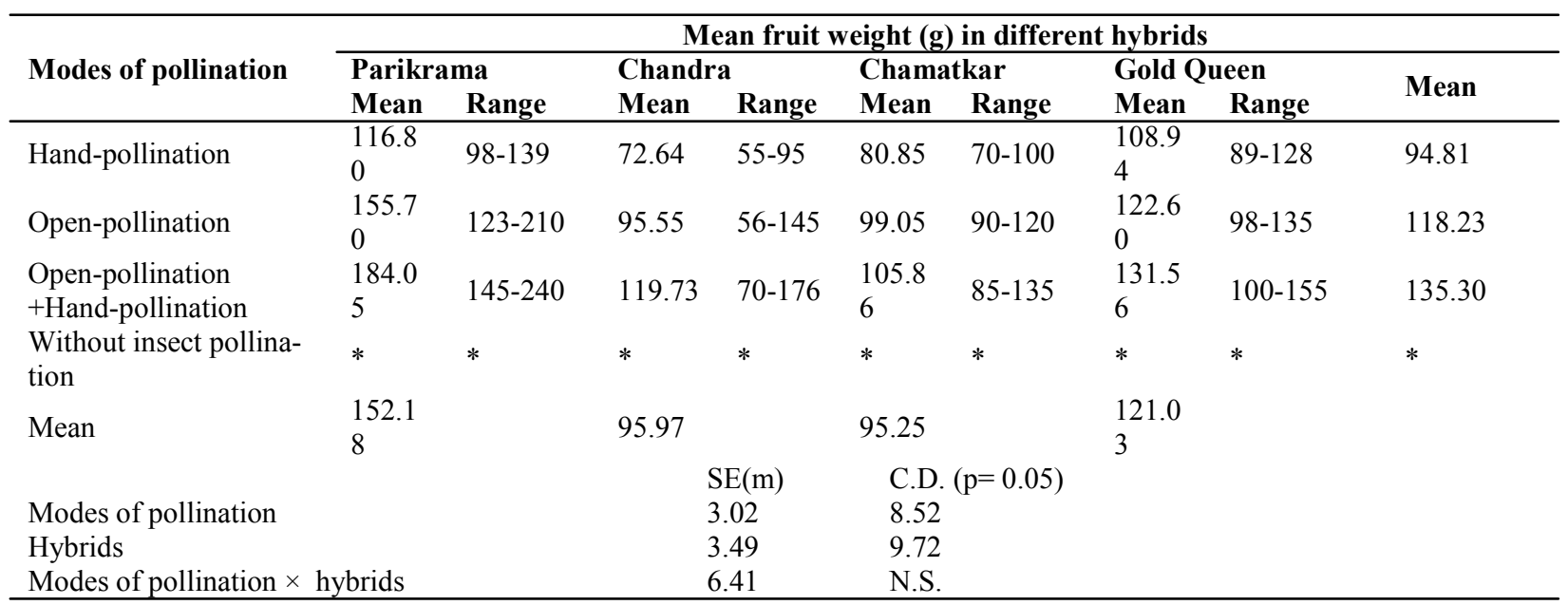

* No fruit formation ( $0 \%$ fruit set) was observed under without insect pollination treatment.

hand-pollination was $2.90 \mathrm{~cm}$ (range $2.10-3.50 \mathrm{~cm}$ ) in Parikrama, $3.65 \mathrm{~cm}$ (range 3.24-4.23) in Chandra, 3.42 $\mathrm{cm}$ (range 3.25-4.80 cm) in Chamatkar and $3.90 \mathrm{~cm}$ (range 3.98-4.70) in Gold Queen, respectively.

Effect of different modes of pollination on fruit polar diameter: The data with respect to the effect of modes of pollination on fruit polar diameter in different hybrids of summer squash have been given in table 3. The average fruit diameter of different hybrids in open-pollination + hand-pollination $(3.74 \mathrm{~cm})$ was significantly higher than the average fruit diameter in hand-pollination $(2.14 \mathrm{~cm})$ and open-pollination $(2.40$ $\mathrm{cm})$ treatments. Irrespective of different modes of pollination, the mean fruit diameter of Gold Queen (2.95 $\mathrm{cm}$ ) was observed maximum and it was par with Chandra $(2.83 \mathrm{~cm})$, and the former was significantly higher than the mean fruit polar diameter of Chamatkar $(2.66 \mathrm{~cm})$ and Parikrama $(2.60 \mathrm{~cm})$ hybrid. The interaction between different modes of pollination and different hybrids was non-significant. No fruit formation was observed in the treatment without insect pollination. The perusal of data in table 3 reveals that the mean fruit polar diameter was recorded $2.14 \mathrm{~cm}$ (range 2.12$2.45 \mathrm{~cm}$ ) in Parikrama, $2.13 \mathrm{~cm}$ (range 2.11-2.98 cm) in Chandra, $2.17 \mathrm{~cm}$ (range 2.11-2.98 cm) in Chamatkar and $2.11 \mathrm{~cm}$ (range 2.12-2.64 cm) in Gold Queen hybrid under hand-pollination treatment. It was 2.26 $\mathrm{cm}$ (range 2.26-2.35 cm) in Parikrama, $2.24 \mathrm{~cm}$ (range 2.23-2.69 cm) in Chandra, $2.16 \mathrm{~cm}$ (range 2.12-2.26 $\mathrm{cm}$ ) in Chamatkar and $2.95 \mathrm{~cm}$ (range $2.92-3.23 \mathrm{~cm}$ ) in Gold Queen hybrid in open-pollinated plants. Similarly, the mean fruit diameter in open-pollination + hand-pollination was $3.40 \mathrm{~cm}$ (range $2.61-3.92 \mathrm{~cm}$ ) in Parikrama, $4.12 \mathrm{~cm}$ (range 3.62-4.62) in Chandra, 3.65 $\mathrm{cm}$ (range $3.25-4.20 \mathrm{~cm}$ ) in Chamatkar and $3.80 \mathrm{~cm}$ (range 3.12-4.70) in Gold Queen, respectively. Hanh (2008) reported that the mean fruit diameter of different cucumber hybrids was maximum under openpollination + hand-pollination $(3.78 \mathrm{~cm})$ and open- pollination $(3.76 \mathrm{~cm})$, which were significantly higher than the hand-pollination $(3.64 \mathrm{~cm})$ and selfpollination $(0.71 \mathrm{~cm})$.

Effect of different modes of pollination on fruit weight:The data regarding the effect of modes of pollination on fruit weight in different summer squash hybrids have been given in Table 4 . The average fruit weight registered was maximum $(135.30 \mathrm{~g})$ with openpollination + hand-pollination treatment, which was significantly higher than the mean fruit weight under open-pollination (118.23 g) and hand-pollination (94.81 g). The present studies corroborate with work of Hanh (2008) who also observed the maximum mean fruit weight under open-pollination + hand-pollination $(159.62 \mathrm{~g})$, which was on par with mean fruit weight under open-pollination (158.55 g) treatment, and the lowest mean fruit weight was observed under selfpollination $(21.10 \mathrm{~g})$. Irrespective of different modes of pollination, the mean fruit weight of Parikrama hybrid was observed maximum (152.18 g), which was significantly higher than the mean fruit weight of Gold Queen (121.03 g), Chandra (95.97 g) and Chamatkar $(95.25 \mathrm{~g})$. The interaction between different modes of pollination and different hybrids for mean fruit weight showed non-significant difference.

The data depicted that the mean fruit weight was recorded $116.80 \mathrm{~g}$ (range 98-139 g) in Parikrama, 72.64 $\mathrm{g}$ (range 55-95 g) in Chandra, $80.85 \mathrm{~g}$ (range 70-100 g) in Chamatkar and $108.94 \mathrm{~g}$ (range 89-128 g) in Gold Queen hybrid in hand-pollinated plants. It was 155.70 g (range 123-210 g) in Parikrama, $95.55 \mathrm{~g}$ (range 56$145 \mathrm{~g}$ ) in Chandra, $99.05 \mathrm{~g}$ (range 90-120 g) in Chamatkar and $122.60 \mathrm{~g}$ (range 98-135 g) in Gold Queen in open-pollinated plants. Similarly, the mean fruit weight in open-pollination + hand-pollination treatment was 184.05 (range 145-240 g), 119.73 (range 70$176 \mathrm{~g}$ ), 105.86 (range 85-135 g) and $131.56 \mathrm{~g}$ (range 100-155 g) in Parikrama, Chandra, Chamatkar and Gold Queen hybrid, respectively. 
Similar results were reported by Cervancia and Bergonia (1991) who found that per cent fruit set of beepollinated and open-pollinated (uncaged) plants in Philippines was about twice that of non-pollinated plants. They further confirmed the present findings by recording shortest and lightest $(0.36 \mathrm{~kg})$ fruits from non pollinated plots. Many research workers like Nogueira and Calmona (1993) and Walters and Taylor (2006) reported more number of fruits $/ \mathrm{m}^{2}$ and heavier and higher quality fruits in plots netted with bees than other plots. Kumar (2004) also reported that the average fruit diameter, fruit length and fruit weight was maximum $(3.51 \mathrm{~cm}, 13.31 \mathrm{~cm}$ and $135.25 \mathrm{~g}$, respectively) under bee pollination and bee pollination + hand-pollination, while these were minimum $(3.49 \mathrm{~cm}$, $12.19 \mathrm{~cm}$ and $132.83 \mathrm{~g}$, respectively) in handpollination conditions under polyhouse conditions during Rabi season in Hisar. The above findings were also supported by Hanh (2008) who found that mean fruit weight under open-pollination + hand-pollination (159.62 g), was at par with open-pollination (158.55 g) treatment but both differ significantly from selfpollination $(21.10 \mathrm{~g})$. Similar results were reported by Pavana (2010) that irrespective of different hybrids, the treatment open-pollination + hand-pollination and open-pollination produced the maximum number of fruits per plant (74.00 and $72.50 \%$, respectively) followed by hand-pollination $(58.38 \%)$. The least or zero per cent fruit set was observed in without insect pollination (WIP) treatment. Though Prakash et al. (2004), Santos et al. (2008) and Thakur and Rana (2008) reported higher fruit size and weigh in bee pollinated plot as compared to open pollinated and hand pollinated plots.

The larger fruit size and weigh in open pollinated plants might be attributed to the sufficient number of pollen grains received by the flowers which were best provided by honey bees in caged conditions as compared to HP. Delaplane and Mayer (2000) also advocated that the number of pollen grains deposited on the stigma by pollinators are directly related to seed formation, which often determines fruit size .

\section{Conclusion}

Effect of different modes of pollination on yield parameters of summer squash showed that maximum fruit set $(73.50 \%)$ was observed under open-pollination + hand-pollination treatment whereas no fruits set was observed under without insect pollination treatment. Average fruit weight, fruit polar diameter and equatorial diameter was also found maximum $(135.30 \mathrm{~g}, 3.74$ $\mathrm{cm}$ and $3.47 \mathrm{~cm}$, respectively) under Open-pollination + hand-pollination as compared to hand-pollination treatment $(94.81 \mathrm{~cm}, 2.14 \mathrm{~cm}$ and $2.48 \mathrm{~cm}$, respectively). It is therefore concluded that open pollination by honey bees and wild pollinators should be ensured particularly in low pollinator activity areas to enhance the yield and quality of summer squash fruits. Thus in low natural pollinators activity area greater revenues can be generated by using hive bees.

\section{REFERENCES}

Cervancia, C.R. and Bergonia, E.A. (1991). Insect pollination of cucumber (Cucumis sativus L.) in the Philippines. In: Proceedings of the Sixth International Symposium on Pollination, Tilburg, Netherlands, 27-31 August 1990, pp. 278-282.

Delaplane, K.S, Mayer, D.F. (2000). Crop pollination by bees. CABI Publishing, New York.

Free, J.B. (1992). Insect Pollination of Crops. Academic Press, London, England, 684 p.

Hanh, T.T.M., 2008. Studies on insect pollinators of cucumber (Cucumis sativus L.). M.Sc. Thesis, CCS Haryana Agricultural University, Hisar, Haryana, India.

Hodges, L. and Baxendale, F. (1991). Bee pollination of cucurbit crops. Report of University of Nebraska, Lincoln Cooperative Extension, NF91-50

Kumar, R. (2004). Role of Apis mellifera L. in pollination of cucumber (Cucumis sativus L.) under polyhouse conditions. M.Sc. Thesis, Haryana Agricultural University, Hisar, Haryana, India.

McGregor, S.E. (1976). Insect Pollination of Cultivated Crops, U.S. Department of Agriculture, Agriculture Handbook, $496 \mathrm{pp}$

Melnichenko, A.N. and Khalifman, I.A., 1960. Pollination of Agricultural Crops, Vol. III. Amerind Publication Co. Pvt. Ltd., New Delhi, India, 406pp.

Nepi, M. and Pacini, E. (1993). Pollination, pollination viability and pistil receptivity in Cucurbita pepo. Ann. Bot., 72: 527-536.

Nogueira, C.R.H. and Calmona, R.C. (1993). Insect pollination of cucumber (Cucumis sativus var.Aodai Melhorada). Naturalia Sao Paulo, 18: 77-82.

Pavana, B. (2010). Studies on insect pollinators on bitter gourd (Momordica charantia L.) M.Sc. Thesis submitted to CCS Haryana Agricultural University, Hisar

Prakash, K.B., Sajjanar, S.M., Kuberappa, G., Prabhuswamy, H.P. and Eswarappa, G. (2004). Effect of number of bee visits on fruit set and some fruit characters in Cucurnis sativus L. Advances in Pollen Spore Research, 22: 127130

Santos, S.A.B., Roselino, A.C. and Bego, L.R. (2008). Pollination of cucumber, Cucumis sativus L. (Cucurbitales: Cucuurbitaceae) by the stingless bees Scaptotrigona aff. Depilis Moure and Nannotrigona testaceicornis Lepeletier (Hymenoptera: Meliponini) in greenhouse. Neotropical Entomology, 37(5): 506-512.

Sarwar, G., Aslam, M., Munawar, M.S., Raja, S. and Mahmood, R. (2008). Effect of honey bee (Apis mellifera L.) pollination on fruit setting and yield of cucumber (Cucumis sativus L.). Pakistan Entomologist, 30(2): 185 $-191$.

Thakur, Meena and Rana, RS. (2008). Studies on the role of insect pollination on cucumber yield. Pest Technology, 2(2): 130-133.

Tomar, N. (2013). APMC act in India: rising food inflation a decade story. International Journal of Social Science and Interdisciplinary Research, 2(7): 38-49

Walters, S.A. and Taylor, B.H. (2006). Effect of honeybee pollination on pumpkin fruit and seed yield. Hort Science, 41: 370- 373. 